INTRODUCTION

Moving Forward: New Perspectives on German-Polish Relations in Contemporary Europe

\title{
Friederike Eigler
}

German, Georgetown University

Since the end of the Cold War and the reconfiguration of the map of Europe, scholars across the disciplines have looked anew at the geopolitical and geocultural dimensions of East Central Europe. Although geographically at the periphery of Eastern Europe, Germany and its changing discourses on the East have also become a subject of this reassessment in recent years. Within this larger context, this special issue explores the fraught history of German-Polish border regions with a special focus on contemporary literature and film. ${ }^{1}$ The contributions examine the representation of border regions in recent Polish and German literature (Irene Sywenky, Claudia Winkler), filmic accounts of historical German and Polish legacies within contemporary European contexts (Randall Halle, Meghan O'Dea), and the role of collective memory in contemporary German-Polish relations (Karl Cordell). Bringing together scholars of Polish and German literature and film, as well as political science, some of the contributions also ponder the advantages of regional and transnational approaches to issues that used to be discussed primarily within national parameters.

The German-Polish relationship has undergone dramatic changes over the past century. The shifting borders between between Germany (earlier Prussia) and Poland over the past 200-plus years are the most visible sign of what, until recently, was a highly fraught relationship. To review some of the most important cartographic shifts:

- The multiple partitions of Poland between Russia, the Habsburg Monarchy, and Prussia in the late eighteenth century resulted in the disappearance of the Polish state for 120 years. 
- After World War I, the Treaty of Versailles stipulated the reconstitution of the Polish nation state within new borders (including parts of Silesia that had not been part of Poland for more than 600 years).

- After Nazi Germany's attack and occupation of Poland, the infamous Generalplan Ost (Master Plan East) was partially realized. It envisioned a complete reordering of Polish territory including the settlement of ethnic Germans and the forced relocation or annihilation of large groups of Poles.

- As a result of the Potsdam and Yalta Conferences of 1945, the borders of Germany and Poland were redrawn. At the end of the war and in the immediate postwar period, approximately eight million ethnic Germans were expelled from territories that became part of Poland; ${ }^{2}$ furthermore, and this is little known in Germany, approximately one million Poles were forced to relocate from the Eastern territories that Poland lost to the Soviet Union (most of these Polish citizens were moved to the new Western territories of Poland). This process also involved the transfer of almost 500,00 Ukrainians from the territory of postwar Poland to the USSR.

With the end of the Cold War and the Eastern expansion of the European Union (EU) the historically fraught relationship between Germany and Poland has been transformed into a productive and peaceful relationship between EU members. This process was completed only in 2011, when Polish citizens gained full rights to live and work anywhere in the European Union. Momentous political changes, however, do not automatically put an end to long-standing stereotypes. The media coverage in Germany around the time of the 2011 changes was a case in point. It was replete with negative references to an "Eastern flood" of low-wage workers streaming from Poland into Germany, recalling anxieties of reverse diffusion regarding undue Slavic encroachment on "German space" that hark back to nineteenth-century Prussia and Germany. ${ }^{3}$

At the same time, some developments in public discourse and in the cultural realm indicate more nuanced approaches to the Polish-German relationship and a shift away from long-standing national stereotypes and a "culture of entitlement," i.e., a tendency on both sides to conceptualize the German-Polish relationship along the victim-perpetrator opposition (Nazi atrocities from the Polish perspective; expulsion from the German perspective). This juncture thus seems an especially opportune moment to explore "the work of culture"-that is, the ways in which literature and film approach the historical legacies and new potentials of German-Polish rela- 
tions. With a special focus on historically contested border regions the contributions to this special issue discuss the role of literature and film in transforming discourses on German-Polish history and the role of collective memory in shaping contemporary German-Polish relations.

The decades since the end of the Cold War have seen an unprecedented surge in cultural exchange, as well as research focused on East Central Europe in general and on the German relationship to the East, especially to Poland, in particular. New scholarship in historiography and cultural studies was in part facilitated by the opening of archives and national borders after 1990. But, in no small part, it was also fostered by new generations of scholars, writers, and filmmakers who are interested in-but less burdened bythe past and who also look at the potentials and pitfalls of a newly configured Europe. Two projects, one local and one transnational, exemplify these recent developments and the new insights they foster.

\section{The Polish Civic Association Borussia}

Since the end of the Cold War, a number of civic associations have emerged in German-Polish border regions. As grass-roots organizations, they explore the multi-ethnic history of specific localities that run counter to the nation state and to nationalism. ${ }^{5}$ An example is Borussia, a cultural association founded in 1990 and made up of Polish citizens and historians who explore the multinational and multi-ethnic history of former East Prussia. The controversial choice of the name "Borussia," a latinized version of Preussen ("Prussia,") signals the rejection of the idea of a homogenous national heritage and, instead, draws attention to German, Polish, and European cultural traditions. ${ }^{6}$ Its cofounder Robert Traba, who also serves as editor of the group's journal (also titled Borussia) comments on the association's goals in the following manner:

"Borussia" [is] . . . neither just a historical society nor just a Polish-German association. It is enlivened by the experiences of its members' own, very distinct family experiences, by the Polish, German, and multicultural legacy of Masuria, Warmia, and the former East Prussia, and it seeks to build an open society for the future. Its characteristic is the notion of a regionalism that is "open," in a certain sense "universal."7

The approach that Traba terms "open regionalism" emerged after the end of socialism and counteracts in a decentralized fashion the highly centralized and politicized approaches to the border regions that dominated the Cold War: on one side of the Iron Curtain, the socialist supression of the history of forced relocations of Poles and of the multi-ethnic histories of the 
border regions; on the other side, the revisionist and explicitly national agenda of the West German Federation of Expellees (Bund der Vertriebenen), which did not formally acknowledge the post 1945 borders of Poland until 1990. By contrast, regional groups and cultural associations like Borussia emerged from below as grass-roots movements. By exploring the complex history of a particular place or region-including its contemporary legacies such as the persistence of national stereotypes-involved citizens are gaining a new sense of belonging and regional identity. ${ }^{8}$

\section{German-Polish Sites of Memory}

It is a telling coincidence that the Polish historian Robert Traba, i.e., the same person who helped establish the regional association Borussia later assumed the directorship of the research institute and the transnational project I want to introduce next: The Berlin Center for Historical Research of the Polish Academy of Sciences (Zentrum für Historische Forschung Berlin der Polnischen Akademie der Wissenschaften) and its most ambitious research initiative to date on German-Polish Sites of Memory (Deutsch-polnische Erinnerungsorte). As first director of the Berlin Center, Traba has focused his research on German-Polish regional historiography and community projects ${ }^{9}$-illustrating how regional concerns can complement or even foster transnational engagement and perspectives.

The Berlin Center for Historical Research was founded in 2006 and is funded by the Polish government-the first Polish research institute abroad of this kind-and thus serves as a counterpart to the German Historical Institute in Warsaw. The Center supports research projects, conferences, and public events on German-Polish history and German-Polish relations, addressing the scholarly community as well as the general public. As such, it exemplifies not only new venues for research, but also the potential for bilateral and transnational engagements in academic, cultural, and public realms.

In his introduction to the Center's first yearbook, Traba comments on the choice of title, Historie. Referencing the nineteenth-century German term Friedrich Nietzsche used in his famous essay "On the Use and Abuse of History for Life," ("Vom Nutzen und Nachteil der Historie für das Leben," 1874) as well as the contemporary Polish term for both stories and history (historia), Historie symbolically marks an enterprise that involves both countries and multiple research communities. ${ }^{10}$ A case in point is the 2011/2012 issue of the yearbook which takes stock of academic projects and methodological challenges concerning German-Polish regional histories 
(Regionalgeschichte $)^{11}$-a topic that also pertains to the contributions of this special issue.

Beyond academic exchanges and joint research projects, the editorial for the opening issue of Historie stresses the Center's public mission in Germany, namely to rebalance what Traba terms the "asymmetry in GermanPolish relations," i.e., the relative lack of historical knowledge and interest in Poland and Eastern Europe among most Germans today. An example for the Center's educational role is the successful 2009 exhibit "We Berliners: History of a German-Polish Neighborship" (Wir Berliner. Geschichte einer deutsch-polnischen Nachbarschaft) that showcased the little known role of Polish immigrants for the city of Berlin from the eighteenth century to the present. ${ }^{12}$

The ambitious project "German-Polish Sites of Memory" initiated by the Center shortly after its foundation in collaboration with the University of Oldenburg, constitutes not only a comprehensive response to this diagnosed lack of historical awareness, but also a major scholarly achievement. ${ }^{13}$ Adopting a broad notion of "sites" or "realms" of memory, one that includes geographical and figurative sites, the project investigates approximately one hundred places as well as historical and cultural phenomena that have played a central role in the histories and cultural memories of both countries. One of the project's most innovative conceptual features is the notion of "parallel sites of memory." The term references historical or cultural phenomena that are specific to each country's national memory, but that fulfill similar or overlapping roles.

In the context of this special issue, a particularly relevant example for parallel sites of memory is "Kresy and the German East." ${ }^{14}$ Scholars examine the roles of the Eastern territories of pre World War II Poland (i.e., kresy-in today's Ukraine, Belarus, and Lithuania) and of Germany (the "German East"), ${ }^{15}$ which were incorporated into Poland and the Soviet Union respectively as a consequence of World War II-as well as the subsequent expulsion and forced relocation of ethnic Germans and Poles in both cases. Discussing these distinct but parallel sites together, the contribution throws into relief similar discourses on the respective Eastern territories, including their colonial dimension. Despite these similarities, however, the authors also point to significant differences. Because of the partition and dissolution of the Polish state in the eighteenth century, Polish colonial discourse on its "East" remained largely divorced from political realities and instead gained mythologizing or idealizing dimensions. By contrast, the long history of Prussian military expansion-and the Polish countermovements-fed directly into a colonial rhetoric which, in turn, made military aggression "in defense 
of the German East" widely acceptable among many Germans, especially in response to the creation of a Polish state after World War I.

The analysis of parallel sites of memory such as "Kresy and the German East" intervenes in dominant public perceptions and helps to put phenomena into perspective that are often seen as particular to one national tradition. Another instructive example of parallel sites of memory, this time a figurative one, is the comparative analysis of German writer Gustav Freytag and Polish writer Henryk Sienkiewicz. As Izabela Surynt explains, over the course of the nineteenth century both writers became icons in the collective memory of their respective countries as their works were perceived as advocating a sense of national identity and nationalistic pride. In Prussia and later Germany, Freytag's novel Soll und Haben (Debit and Credit) fostered national chauvinism vis-à-vis Poles and Eastern Jewry while Sienkiewicz's historical novels idealized Polish victories over various adversaries. These parallel functions started diverging after World War II. While Freytag remained popular only on the fringes of West German society-e.g., among expellees and expellee organizations-Sienkiewicz continued to be idealized widely during the communist period in light of Polish opposition to Soviet dominance. ${ }^{16}$

The comprehensive project on "German-Polish Sites of Memory" is of interest also in terms of its transnational methodological objectives. Responding to the critical reception of Pierre Nora's comprehensive national history of France titled Les Lieux de Mémoire (1984-1992; Realms of Memory, 19961998), ${ }^{17}$ the German-Polish initiative challenges a national approach, as indicated by the title. But, it also seeks to go beyond a traditional binational approach. First, it considers the shifting roles and relationships of multiple ethnic and national groups that make up and to some extent challenge each nation. (Many of the sites included in this project do not only involve German and Polish history but also aspects of Ukrainian, Lithuanian, White Russian (Byelorussian), Habsburg, and Jewish history.) Second, the project combines the history of German-Polish relations (Beziehungsgeschichte) ${ }^{18}$ with historiography of the second degree, i.e., the reception and memorialization of historical events and phenomena. The project as a whole is thus shaped by a high level of methodological reflection and metacritical awareness, a dimension that is the focus of volume four of Deutsch-polnische Erinnerungsorte, titled Reflexionen (Reflections).

The final results of this multi-year project started appearing in print in 2012 in both German and Polish. ${ }^{19}$ While the publication itself is a major accomplishment, in the larger context of shifting national and academic discourses that provide the backdrop for the contributions to this special issue, 
the collaborative efforts that preceded and shaped the publication are just as significant. In contrast to other major publications on sites of memory this one neither adopted a top-down nor a quantitative approach (e.g., selection based on surveys), but a qualitative approach based on several rounds of deliberations among a diverse group of scholars. ${ }^{20}$ Overall, the project illustrates the extent to which a collaborative transnational approach can intervene in scholarly discourse by shaping the content and result of specific research projects. Furthermore, the coordinated publications in both German and Polish address scholars and the general public in both countries. Considering the Center's role in the city of Berlin, the research initiative represents a significant intervention in public and academic discourse.

The comprehensive transnational project on "German-Polish Sites of Memory" contributes to the burgeoning scholarship on the history of German discourses on Eastern Europe, including Poland, and on some of the real historical consequences of these discourses for border regions in East Central Europe. These areas of research are not new but many of the recent publications take post 1989 Europe as a point of departure for revisiting the histories of vexed border issues across Europe-their legacies and contemporary transformations. The remainder of this introduction surveys some of this recent scholarship on the history of German discourses on the East and on contemporary European borders and border regions-all of which provide context for the contributions to this special issue.

\section{Borders and Border Regions}

The 2012 volume Walls, Borders, Boundaries, edited jointly by scholars in German studies (Marc Silberman), cultural geography (Karen E. Till), and history (Janet Ward), takes "the epistemic break of the fall of the Berlin wall" ${ }^{21}$ as the point of departure for an exploration of a wide range of border issues that concern the historical, political, social, and cultural make-up of contemporary Europe. In their introduction, the editors call attention to the "polyvocal possibilities of multicultural zones" and warn against employing fixed spatial categories in both political and academic discourses as these might, unwittingly, contribute to counterproductive perceptions of geographical borders (i.e., perceptions based on static or binary thinking). ${ }^{22}$ Contributions to the volume illustrate that a consideration of these "polyvocal possibilities" includes such issues as power relations, social and political conflict, as well as conflict resolution in border regions. For instance, in "Moving Borders and Competing Civilizing Missions," 
Steffi Marung explores the new role and self-positioning of Poland in the context of its accession to the European Union in $2004 .{ }^{23}$ Focusing on the changing discursive boundaries that separate "East" and "West," she explores Poland's strategic use of the discourse of a "civilizing mission"traditionally associated with the West-vis-à-vis its Eastern neighbors, especially Ukraine. According to Marung, Poland's discursive self-positioning as a bridge between East and West contributed to political change as evidenced in the active role of Polish officials in codifying EU agreements with its new Eastern member states following the 2004 enlargement. Marung's reference to notions of a "civilizing mission" in Poland throws into relief the dramatic changes in Poland's real and imagined position within contemporary Europe.

Walls, Borders, Boundaries also illustrates the potential of engaging with border issues from multiple disciplinary perspectives. The focus on issues of space and borders creates multiple connections that, taken together, have the effect of disciplinary border crossings and of charting "the new territory of transdisciplinary border studies." ${ }^{24}$ Unfortunately, this otherwise impressive volume does not include any contribution from literary or film studies. Nevertheless, the editors' concluding appeal also pertains to the focus of this special issue on German-Polish border regions:

We invite our readers to reconsider ... how borders are invested with meaning and by whom; the political inevitability, psychological necessity, and creative challenge of such spaces and places; and alternative mappings of the frailties of the human de- and re-territorializing imagination. ${ }^{25}$

This special issue of German Politics and Society illustrates the extent to which literature and film are in a unique position to reflect on how "borders are invested with meaning" and to explore "alternative mappings of the frailties of the human de- and re-territorializing imagination." Taken together, the contributions engage the overarching claims of Walls, Borders, Boundaries in a critical dialogue by focusing on an area of inquiry-literature and filmthat is missing from the edited volume.

In response to the changing map of Europe since the end of the Cold War, research in border studies ${ }^{26}$ has increasingly pointed to the potential of border areas for developing regional identities and regional literaturesphenomena that limit, counteract, and in some cases transcend the role of the nation and national history. The German-Polish anthology Granica: Die deutsch-polnische Grenze vom 19. bis zum 21. Jahrhundert (Granica: The German-Polish Border from the Nineteenth to the Twenty-First Century, 2010) includes contributions by a mostly younger generation of German and Polish scholars on both the enabling and the disabling impact of borders. 
As the editors Karoline Gil and Christian Pletzing mention in their introduction, the Polish term "Granica" (border) is etymologically related to the German term "Grenze"-and thus symbolically marks the transnational approach that informs many contributions to the volume. ${ }^{27}$ Several of them examine the history of the German-Polish border and showcase the detrimental role of the nation state and nationalism. Granica also includes essays on post 1990 German-Polish border regions that illustrate not only continued challenges but also new potentials for collaboration and communication across and beyond national borders. ${ }^{28}$

These potentials-as well as the historical specters that might complicate them-are symbolically captured on the book cover, which displays a 2002 photo of a group of teenagers in colorful biking outfits opening a barrier at the German-Polish border. This image references and turns on its head the infamous photo of a group of German soldiers who forcefully remove a similar barrier at the outset of World War II. This latter image is featured on the cover of the 1972 paperback edition of Martin Broszat's influential study Zweihundert Jahre deutsche Polenpolitik (Two Hundred Years of German Policy toward Poland). ${ }^{29}$ Taken together, these two images symbolically mark the historic transformation from military aggression to civilian border crossing within the enlarged European Union.

A brief consideration of Broszat's comprehensive study underscores the significance of this transformation. Zweihundert Jahre deutsche Polenpolitik focuses on the long and vexed history of German, and especially Prussian, politics and discourses vis-à-vis the Polish neighbor from the eighteenth to the twentieth century. To this date Broszat's book, first published in 1963, continues to be a major source of reference for research on Germany's relationship to Poland and Eastern Europe. Today, the work of historian Gregor Thum exemplifies approaches that expand a national perspective by placing the particulars of German/Prussian history as researched by Broszat, among others, into transnational contexts. For instance, in his contribution to Granica, Thum places nineteenth-century German discourses on the East in global contexts of European colonialism and North American's settlement of the continent's Western territories. ${ }^{30}$ Not unlike the North American notion of the Western "frontier," the Eastern border was seen as "dynamic" and thus adjustable according to political interests. Not unlike European colonialism, eastward expansion, i.e., the occupation and annexation of territories to the East, were legitimized as a "civilizing mission" of the supposedly "superior" German people vis-à-vis the Slavic peoples. ${ }^{31}$ 


\section{Beyond Colonial Discourses}

Thum's work contributes to recent scholarship on the history of German discourses on the East $^{32}$ that examines the emergence of colonial discourses on Eastern Europe and Slavic peoples. For instance, in the introduction to the 2009 volume Germans, Poland, and Colonial Expansion to the East: 1850 to the Present, Robert Nelson argues against the "salt water thesis," i.e., the assumption that European colonial practices were limited to territories overseas. He identifies the following colonial themes in nineteenth- and twentieth-century German approaches to the East, in particular to Poland and the Polish people: "The frontier, the 'emptiness,' the racism, the laboratory: all point toward another chapter in the history of colonialism." The colonial discourses and practices Nelson identifies coincide with a long Orientalist tradition of defining (Western) Europe and (Western) civilization visà-vis its Eastern "other." ${ }^{33}$ As research along these lines demonstrates, literary bestsellers, most notably Gustav Freytag's Soll und Haben, ${ }^{34}$ and academic disciplines, first and foremost the rise of geography, contributed to fostering this colonial approach vis-à-vis the East, especially Poland. ${ }^{35}$

There is, of course, no linear connection between these colonial discourses and the extreme military aggression of Nazi Germany-epitomized in the Generalplan Ost and the fascist fantasy of complete control over the East. Yet, a range of historical, cultural, and literary constellations helped to popularize the discursive subjugation of Poles and other Slavic people and made their actual subjugation-given a particular political and ideological constellation-widely acceptable. Taken together, the broad disciplinary outlook and transnational context within which much of the recent research has emerged provides insights into the ways in which historical events and political practices were shaped by a range of discourses often considered outside the realm of history and politics.

The above survey of some recent scholarship reminds us of the historical reasons for the still fickle-albeit radically transformed-German-Polish relationship today. ${ }^{36}$ Beyond the collective Polish memory of Germany's military aggression in the twentieth century it is instructive to keep in mind the inherently destabilizing notion of a "flexible" Eastern border harking back to nineteenth-century imperial Germany. Arguably, the long history of the "German civilizing mission in the East" came officially to an end with the Warsaw Treaty, signed by Willy Brandt during his historic Warsaw visit in 1970. ${ }^{37}$ But only the 1990 German-Polish Border Treaty (part of the Twoplus-Four Treaty) confirmed the finality of the German-Polish border as an integral part of a unified Germany. 
Considering how recent these major milestones in German-Polish relations are, it is not surprising that collective memories of the highly contentious history of this relationship continue to color current political discourses (see Cordell's contribution to this special issue), as well as aspects of popular culture (as illustrated in some of the documentaries discussed by Halle). ${ }^{38}$ It is perhaps more surprising that writers and film makers in both countries have also found new and productive ways to address these complex sites of memory.

\section{The Contributions to this Special Issue}

The essays in this special issue on German-Polish border regions contribute to the broader objectives of the project on German-Polish Sites of Memory introduced above. Arguably, literature and film provide unique opportunities for exploring and commenting on specific sites of memory in ways that foreground either implicitly or explicitly their multi-ethnic and transnational dimensions as conceptualized by Moritz Csáky. In contradistinction to the national approach to cultural memory that Nora practices in his history of France, Csáky advocates an approach that explores translocal cultural dimensions both regarding the emergence of specific sites of memory and regarding their reception. ${ }^{39}$ This approach is of particular importance for the memory of German-Polish border regions-historically a highly contested site of memory. By adopting a translocal approach, literature and film hold the potential for making specific geographical places relevant to readers and viewers beyond and outside of these locations.

Prominent examples for "real" and figurative "sites of memory" in contemporary literature and film discussed in the present issue are the Polish novels by Olga Tokarczuk and Stefan Chwin (Sywenky), a recent German novel by Sabrina Janesch (Winkler), as well as German documentaries and feature films (Halle, O'Dea). While Halle provides a critical overview of documentaries on flight and expulsion and on films that engage with contemporary border regions and their current inhabitants, O'Dea provides an in-depth analysis of Robert Thalheim's Am Ende kommen Touristen (Along Come Tourists), a 2008 feature film that focuses on contemporary GermanPolish relations at the memory site of Oświęcim/Auschwitz. Irene Sywenky introduces post Cold War Polish literature, including Stefan Chwin's Hanemann (1995, Death in Danzig) and Olga Tokarczuk's Dom dzienny, dom nocny (1998, House of Day, House of Night) as well as Andrzej Stasiuk's travelogue Jadqc do Babadag (2004, On the Road to Babadag). Recalling Csáky's focus on 
the "translocal" dimensions of specific geographical sites of memory, she illustrates how these texts approach places like Silesia and Danzig/Gdansk by incorporating a range of voices, memories, and intertexts. Claudia Winkler's analysis of the 2010 novel Katzenberge (Cat Mountains) by Sabrina Janesch complements Sywenky's contribution on Polish literature by showing how a young German author explores the fraught histories of two border regions, the German-Polish and the Polish-Ukrainian (kresy). All four contributions illustrate how films and novels invest borders and border regions with new meaning. Taken together, the work of culture discussed in these contributions indicates a shift towards regional or transnational approaches to the fraught national histories of specific places and border regions.

Lest one should come away with overly optimistic impressions regarding the role of film and literature in shaping new perceptions of German-Polish relations in contemporary Europe, Cordell's article reminds us that collective memories of past injustices continue to dominate certain segements of German and Polish society-represented in Germany most notably by the Federation of Expellees. Yet, the ways in which, for instance, the controversial plan for a Center against Expulsions, promoted by the Federation, was reconceptualized and turned into a federally funded, research-based foundation suggests that we are slowly moving beyond the political instrumentalization of the vexed German-Polish historical relationship. Taken together, the contributions to this special issue of German Politics and Society offer new perspectives on German-Polish border regions in contemporary literature, film, and political culture within a theoretical framework that straddles regionalism and transnationalism.

\section{Notes}

1. The contributions assembled here are based on an interdisciplinary symposium held at Georgetown University in the spring of 2013.

2. Estimates of the total number of ethnic Germans expelled from Eastern Europe vary between 12 and 14 million, in part because the number of casualties in the context of flight and expulsion remains a matter of dispute.

3. Kristin Kopp, Germany's Wild East. Constructing Poland as Colonial Space (Ann Arbor, 2012), 110-112.

4. Kristin Kopp and Joanna Niżyńska, "Introduction: Between Entitlement and Reconciliation: Germany and Poland's Postmemory After 1989," in Germany, Poland and Postmemor- 
ial Relations: In Search of a Livable Past, eds., Kristin Kopp and Joanna Niżyńska (New York, 2012), 1-24, here 4-6.

5. For an overview of regional associations and projects in German-Polish border regions since 1989, see Robert Traba, "Regionalismus in Polen: die Quellen des Phänomens und sein neues Gesicht nach 1989," in Regionale Bewegungen und Regionalismen in europäischen Zwischenräumen seit der Mitte des 19. Jahrhunderts, eds., Philip Ther and Holm Sundhaussen (Marburg, 2003), 275-283.

6. Traba (see note 5), 280.

7. “'Borussia' [ist] ... weder eine rein historische Gesellschaft noch eine rein polnischdeutsche Vereinigung. Sie lebt von den Erfahrungen der eigenen, verschiedensten Familientraditionen, vom polnischen, deutschen und multikulturellen Erbe Masurens, des Ermlandes und des ehemaligen Ostpreußens und möchte gerade daraus in der Zukunft eine offene Gesellschaft bauen. Ihr Kennzeichen ist der Begriff des 'offenen', in gewissem Sinne 'universellen' Regionalismus." Robert Traba, "Das 'deutsche Kulturerbe' und die Frage nach dem historischen Regionalbewusstsein. "Das Beispiel der Kulturgemeinschaft 'Borussia'," in Deutsche Geschichte und Kultur im heutigen Polen. Fragen der Gegenstandsbestimmung und Methodologie, ed., Hans-Jürgen Karp (Marburg, 1997), 67-72, here 68. All translations are the author's.

8. The projects supported by Borussia include workshops for German and Polish youth aimed at fostering awareness of and interest in regional history. Traba (see note 7), 69-71.

9. See Traba's comments on his roles as scholar and "actor on the stage of the German-Polish debates on collective memory" Historie: Jahrbuch des Zentrums für historische Forschung Berlin der polnischen Akademie der Wissenschaften, no. 1 (Leverkusen-Opladen, 2008), 127.

10. Traba (see note 9), 8-10.

11. See, for instance, Dan Gawrecki and Ryszard Kaczmarek's discussion of the recently completed comprehensive history of Upper Silesia, co-authored by a large group of Polish, Czech, and German historians: "Geschichte Oberschlesiens. Drei Nationen-eine Publikation," Historie, no.5 (2012): 195-202.

12. Iwona Meier, "Eine Ausstellung und ihre Resonanz. Ein Bericht," Historie, no. 2 (2009): 217-225.

13. The project's principal organizers were Robert Traba and Hans Henning Hahn, professor for East European history in Oldenburg, and their assistants Maciej Górny and Kornelia Kończal.

14. Christoph Kleßmann and Robert Traba, "Kresy und deutscher Osten: vom Glauben an die historische Mission-oder Wo liegt Arkadien?," in Deutsch-polnische Erinnerungsorte, eds., Hans Henning Hahn and Robert Traba, vol. 3 (Paderborn, 2012), 34-70.

15. The geographical referent for the term "Eastern territories" changed over time and shrunk from an imagined, open-ended space with some German settlements (the nineteenth-century "frontier") to the lost Eastern territories that were part of pre World War I Germany and, in some instances, still part of the interwar borders of Germany. Kleßmann and Traba (see note 14), 57.

16. Izabela Surynt, "Gustav Freytag und Henryk Sienkiewicz," in Hahn and Traba (see note 13), 331-334.

17. For a brief overview of the critical reception of Nora's approach, see Historie no.2 (2009), especially the contributions by Etienne François, 91-102; and Georg Kreis, 103-117.

18. The historian Klaus Zernack established a historiographical approach that focuses on the history of German-Polish relations. See Maciej Górny, et al. "Zur Einführung," in Hahn and Traba (see note 14), 11-20.

19. For a brief overview of all volumes of Deutsch-polnische Erinnerungsorte, see the introduction by Górny et al. to the third volume, the first one to appear (see note 14), 13-16. For more detailed information, see Kornelia Kończal, "Deutsch-Polnische Erinnerungsorte: wie die deutsch-polnische Beziehungsgeschichte neu konzeptualisiert werden kann," Historie, no.2 (2009): 118-137. 
20. Adopting an unusual bottom-up approach from the outset, the initial deliberations by forty scholars from Germany and Poland over the course of two years contributed to the project's overall scope and approach. During a series of subsequent workshops, historians and scholars of literary and cultural studies continued to discuss all aspects of the project, including the criteria for the selection of sites, the choice of sites of memory, work in progress, and transdisciplinary methodological considerations. See Kończal (see note 19), 126.

21. Marc Silberman, Karen Till, and Janet Ward, "Introduction," Walls, Borders, Boundaries: Spatial and Cultural Practices in Europe (New York, 2012), 17.

22. Ibid., 9 .

23. Steffi Marung, "Moving Borders and Competing Civilizing Missions: Germany, Poland, and Ukraine in the Context of the EU's Eastern Enlargement," in Silbermann, Till, and Ward (see note 21), 131-149, especially 142-144.

24. Silberman, Till, and Ward (see note 21), 17. Examples are overlapping considerations on real and symbolic spaces and boundary crossings in contributions on otherwise highly diverging political and historical constellations in contemporary Albania, Germany, and Cyprus.

25. Ibid., 17.

26. For a summary on the history of border studies, see Vladimir Kolossov, "Theorizing Borders. Border Studies: Changing Perspectives and Theoretical Approaches," Geopolitics vol. 10 (2005): 606-32.

27. Karoline Gil and Christian Pletzing, "Granica-Grenze," in Granica: Die deutsch-polnische Grenze vom 19. bis zum 21. Jahrhundert, eds., Karoline Gil and Christian Pletzing (Munich, 2010), 3-11, especially 7-9.

28. See for instance Bernadette Jonda's discussion of German-Polish cooperation on a range of practical and cultural issues in the border region of Stettin/Szczecin, "Neue Formen des Zusammenlebens-oder Rückkehr zur Normalität?," in Gil and Pletzing (see note 27), 153-72.

29. Martin Broszat, Zweihundert Jahre deutsche Polenpolitik [1963], (Frankfurt/Main, 1990).

30. Gregor Thum, "Eine deutsche Frontier? Die deutsch-polnische Grenze und die Ideen von 1848," in Gil and Pletzing (see note 27), 19-28.

31. Ibid., 24-25. As Thum points out, despite these parallels the German situation was quite distinct from both the North American frontier and from European colonialism overseas. For instance, in stark contrast to the American frontier, the German "frontier" was mostly an imagined one. Ironically, the actual population movement occurred in the opposite direction. Over the course of the nineteenth century, Slavic settlers moved into areas that were predominantly populated by a German-speaking population, a development that Otto von Bismarck sought to reverse by establishing a special settlement commission for West Prussia and Posen in 1886.

32. See, for instance, Gregor Thum, ed., Traumland Osten. Deutsche Bilder vom östlichen Europa im 20. Jahrhundert (Göttingen, 2006); Ulrich Wergin and Karol Sauerland, eds., Bilder des Ostens in der deutschen Literatur (Würzburg, 2009); Gunther Gebhard, Oliver Geisler, and Steffen Schröter, eds., Das Prinzip “Osten.” Geschichte und Gegenwart eines symbolischen Raums (Bielefeld, 2010); Gil and Pletzing (see note 27).

33. Robert Nelson, "Introduction: Colonialism in Europe? The Case Against Salt Water," in Germans, Poland, and Colonial Expansion to the East: 1850 to the Present, ed., Robert Nelson (New York, 2009), 1-10, here 7. See also Larry Wolff, Inventing Eastern Europe. The Map of Civilization and the Mind of the Enlightenment (Palo Alto, 1994).

34. See Kopp (see note 3).

35. See Benno Nietzel on the rise of geography and the role of Hermann Aubin's Ostforschung (Research on the East) in the 1920s: "Im Bann des Raums. Der 'Osten' im deutschen Blick vom 19. Jhd. bis 1945," in Nelson (see note 33), 22-49. 
36. See also Oliver Schmidtke's contribution: "The Threatening Other in the East. Continuities and Discontinuities in Modern German-Polish Relations," in Nelson (see note 33), 171-198.

37. Thum points to the iconic kneeling of Willy Brandt in front of the memorial for the Warsaw ghetto uprising during his 1970 visit as a public sign of West Germany's recognition not only of the German war crimes against Poland but also of the postwar German-Polish border (see note 30), 37.

38. See also Jakub Kazecki's article on recent German films that resort to national stereotypes: "Border, Bridge, or Barrier? Images of German-Polish Borderlands in German Cinema of the 2000s," in Cinema and Social Change in Germany and Austria, eds.,Gabriele Mueller and James M. Skidmore (Waterloo, 2012), 207-224.

39. Moritz Csáky, "Die Mehrdeutigkeit von Gedächtnis und Erinnerung. Ein kritischer Beitrag zur historischen Gedächtnisforschung," Digitales Handbuch zur Geschichte und Kultur Russlands und Osteuropas, 18-19; available at http://epub.ub.uni-muenchen.de/603/, accessed 14 November 2013. Csáky adopts this approach in his comprehensive study of urban cultures in the Habsburg Empire around 1900 titled Die Erinnerung der Städte (Vienna, 2010). 